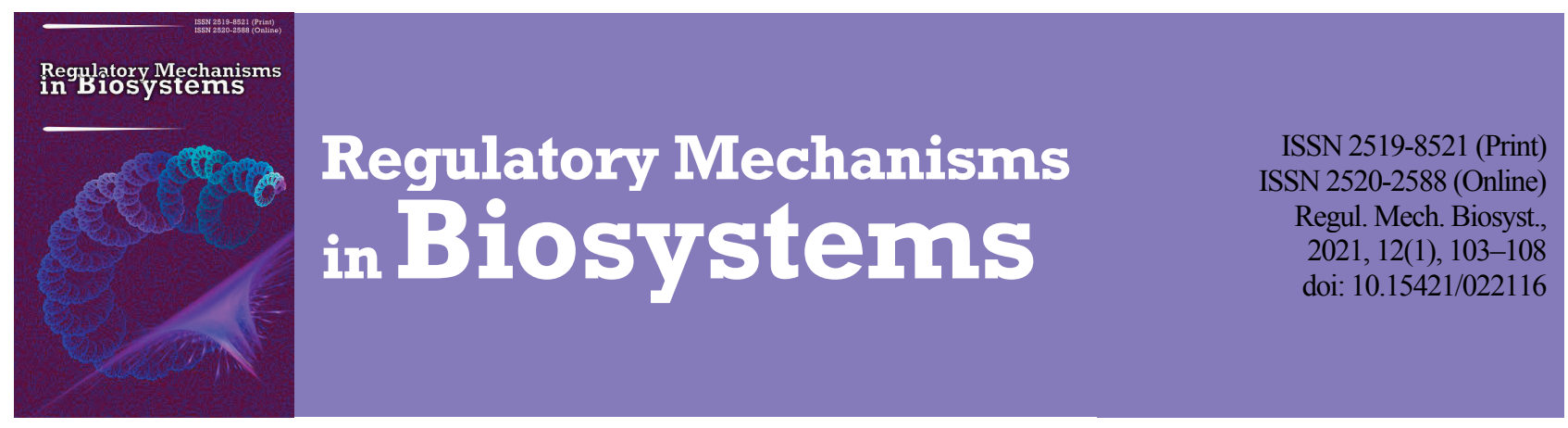

\title{
Level of natremia as an index of the condition of the organism of animals under stress
}

\author{
R. A. Zaprudnova \\ Papanin Institute for Biology of Inland Waters RAS, Borok, Russia
}

Article info

Received 16.02.2021

Received in revised form 11.03.2021

Accepted 12.03.2021

\author{
Zaprudnova, R. A. (2021). Level of natremia as an index of the condition of the organism of animals under stress. Regulatory Me- \\ chanisms in Biosystems, 12(1), 103-108. doi:10.15421/022116
}

In the diagnosis of stressful conditions in humans and other animals, ionic indicators remain practically unused. In this work, we studied the changes in the concentrations of sodium ions in the blood plasma of freshwater fish under stress caused by stressors of different quality and quantity. Most of the experiments were carried out on adult bream (Abramis brama L) from the Rybinsk Reservoir. Separate experiments were duplicated on adult individuals of roach (Rutilus rutilus L.), pike (Esox lucius L.), and blue bream (Abramis ballerus L.).

Papanin Institute

for Biology of Inland

Waters Russian

Academy Science,

Borok, Nekouzsky

Dystrict, Yaroslavl Region

152742, Russia.

Tel.: + $38-485-472-40-42$.

E-mail:raz@ibiw.ru The concentration of cations in the blood plasma was determined using a Flapho-4 flame photometer. Under the action of mild and shortterm stressors of different qualities, the sodium concentration in the internal environment altered toward an increase in concentration gradients on the cell membrane (eustress or physiological stress). Hypernatremia was approximately $10 \%$. Under the action of strong and/or prolonged stressors of different strength, the sodium concentration in the internal environment changed toward a decrease in concentration gradients on the cell membrane (distress or pathological stress). Hyponatremia was 50\% in the conditions of acute lethal stress, $20 \%$ in subacute lethal stress, $10 \%$ or more in chronic lethal stress. During strong acute reversible stress, hyponatremia could reach $30 \%$. Analysis of the material on mammals allowed us to conclude that the adaptation mechanisms in fish and higher vertebrates are similar. In this work, for the first time, the state of the system of electrolyte balance of animals under stress was analyzed from the standpoint of the leading role of ionic concentration gradients on the cell membrane (mainly sodium) in the energetics (level of disequilibrium) of the organism. We propose a concept that in normal and extreme conditions fish use two different defense reactions (or adaptation strategies): active and passive, consisting, respectively, in increasing or decreasing the level of disequilibrium (energy) in the organism. The hyponatremia recorded by numerous authors, which accompanies diseases in humans, is evidently a nonspecific reaction of the organism and serves as an indicator of reduced energy of the organism. It is suggested that the sodium level in the internal environment of the organism be used for diagnosing the stress state of animals.

Keywords: fishes; mammalians; energy of the organism; ion concentration gradients; active and passive defense reaction; eustress; distress.

\section{Introduction}

The problem of stress among people is especially relevant due to deterioration of the ecological conditions, loss of stability and growing tension in the community, eruption of local wars, terrorism, and the coronavirus. Furthermore, a large portion of the population lives under pressure in everyday life due to high social, psycho-emotional loads, intoxications, diseases, etc.

To determine stress condition in people, ion parameters are not used. Most often, for this purpose, cortisol level in blood is analyzed, but also the diagnostics uses parameters of total protein, astrocyte-specific protein $\mathrm{S} 100 \mathrm{~b}$, glucose, activity of aminotransaminase and end-products of metabolism. Diagnostics of fish according to electrolyte balance is extremely rarely conducted: even if studies report the level of natremia, it is considered in a set with other parameters, without consideration of its significance for the organism (Selik, 2004; Akbary, 2014; Martemyanov, 2014). The most intensive research on the influence of stressors on the ion parameters of fish were performed in 1970-1980s. The data varied, sometimes being contradictory and insufficient: most of the data concerning this issue are based on the results of research of response reactions of fish to strong and short term stressors. No generalizing research has been conducted, which would examine a broad range of stress conditions of fish, while the ion criteria of the ill-being of a stressed organism, proposed in some studies, were not broadly used and finally were abandoned completely. Furthermore, the level of natremia was hardly considered at all. Despite the fact that physiological-biochemical processes in fish undergoing stress are being actively studied nowadays (Faught et al., 2016; Rodnick \& Planas,
2016; Takei \& Hwang, 2016), ion parameters of serum (plasma) of blood of fish are not used to identify stress. No data on this issue are available for other vertebrate animals (including the higher vertebrates).

For a long time, in medicine, the norm was considered to be a broad range of changes in the concentration of sodium in the internal environment of the organism (130-150 mmol/L). Thus, the norm was understood not in terms of the thresholds of the physiological fluctuations of this parameter in healthy patients, but in terms of the thresholds of the parameters in the conditions compatible with life. The situation began to change only in the recent 5-10 years: the norm is now identified as a narrower range of natremia $(135-145 \mathrm{mmol} / \mathrm{L})$. At the same time, hyponatremia $(<135 \mathrm{mmol} / \mathrm{L}$ ) in people (Lee et al., 2014; Henry, 2015; Ball \& Iqbal, 2016) occurs more often than hypernatremia $(>145 \mathrm{mmol} / \mathrm{L}$ ) (Reynolds et al., 2006; Muhsin, \& Mount, 2016).

This study on fresh-water fish focused on changes in concentrations of cations of sodium in the internal environment in different stress conditions. Moreover, we discussed the data on mammals, which we found in the literature, indicating patterns of changes in ion content of the internal environment in the conditions of influence of unfavourable factors, which are similar to fish.

\section{Materials and methods}

The main object of the studies was mature and close to-maturity bream (Abramis brama L.) of the Rybinsk Reservoir. Separate experiments were performed on adult individuals of pike (Esox lucius L.), roach (Rutilus rutilus L.) and zope (Abramis ballerus L.) from the same water body. 
Experiments were performed in summer, when water temperature equaled $17-20^{\circ} \mathrm{C}$ in the conditions of acute, subacute and chronic stress with lethal outcome, and also acute reversible stress of different degree of strength and duration. Low stress (Fig. 1) was caused by putting acclimatized fish into limited water volume (ratio of body weight to water was 1:20) with continuous aeration. Strong reversible acute stress was caused by short-term capture of fish in the natural environment (no longer than $15 \mathrm{~min}$ ) and their transportation to the laboratory for 1.5-2.0 hours in a limited volume of water (Fig. 2a, 3a) and rapid change in the temperature by $18{ }^{\circ} \mathrm{C}$ (Fig. 3a). Acute lethal stress lasting 5 to $12 \mathrm{~h}$ was caused by complex action of several strong factors: capture, transportation in a limited volume of water with decreasing oxygen content (to $2.5 \mathrm{mg} / \mathrm{L}$ ) and increasing temperature (to $25^{\circ} \mathrm{C}$, Fig. $2 \mathrm{~b}, 3 \mathrm{~b}$ ) and imitation of all these factors on acclimated fish (Fig. 3b). Subacute stress with lethal outcome lasting 5-18 days was caused by quite strong stressors, which fish could not adapt to: post-traumatic effects of long trawling and hard transportation conditions (Fig. 2c, 3c) and retention of fish in containers (Fig. 3c). Chronic lethal stress lasting 1-3 months was caused by retention of fish in the laboratory conditions against the background of increased light and noise irritators (Fig. 2d, 3d) and in non-favourable conditions of ponds of the experimental base (Fig. 3d). Each experimental point for bream was represented by 11-24 fish, and by 5-9 individuals of other species.

Concentration of cations in blood plasma was analyzed using Flapho-4 flame photometer manufactured by Carl Zeiss (Jena, Germany). The study presents the mean values of concentrations of ions and standard error $(\mathrm{x} \pm \mathrm{SE})$. The normal distribution for the selections was tested using the Shapiro-Wilk criterion. We determined that all the selections had normal distribution. Significance of the differences was assessed using the t-test.

\section{Results}

In the conditions of influence of weak and short-term stressors (Fig. 1), the content of blood sodium of fresh-water fish may increase $10 \%$ on average. Approximately to the same extent, the sodium concentration may decrease during chronic stress with lethal outcome (Fig. 2d, 3d). During subacute stress with lethal outcome, caused by powerful stressors, to which fish was not capable to adapt, hyponatremia reached $20 \%$ (Fig. 2c, 3c). During severe acute stress, loss of sodium from the internal environment reached nearly $50 \%$, thus resulting in the quick death of the animals (Fig. 2b, 3b). Maximal possible hyponatremia, in which fish survive, observed during acute reversible stress, may equal 30\% (Fig. 2a, 3a). There is a direct dependence between the level of hyponatremia and the strength of stressors.

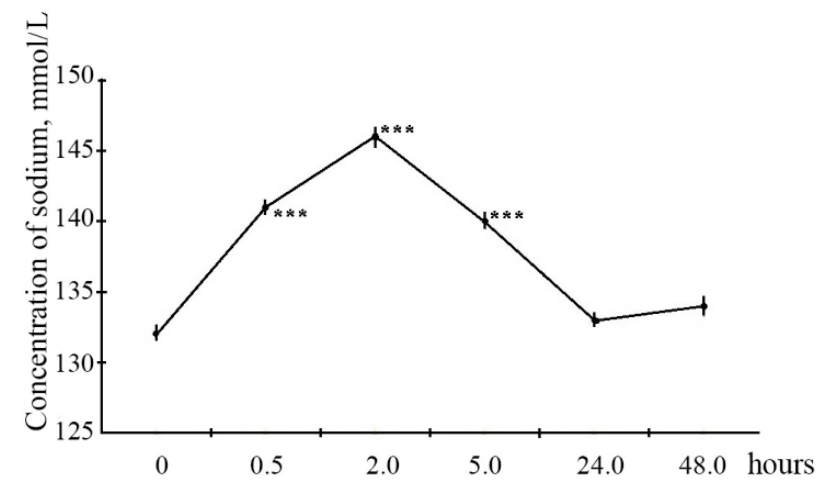

Fig. 1. Dynamics of the sodium concentration in blood plasma during eustress (physiological stress, $\mathrm{mmol} / \mathrm{L}$ ): $* * *-\mathrm{P}<0.001$ compared with the norm

\section{Discussion}

General mechanisms of adaptation were found in the system of electrolyte balance in fresh-water fish, related to the amount (strength and duration) of the stressor. The stressors were classified according to quality. However, the pattern of their action, as demonstrated in this and the earlier articles (Zaprudnova, 2012, 2017), depended on the intensity of the action: during short-term weak actions, there were seen changes toward increase in concentration gradients on the cell membranes (hypernatremia, eustress), while in the conditions of strong or prolonged actions - toward decrease (hyponatremia, distress). At the same time, hyponatremia was seen in all unfavourable conditions.

As demonstrated earlier (Zaprudnova, 2012, 2017), changes the concentrations of other main cations in the internal environment (potassium, calcium, magnesium) during acute stress reaction to short-term weak stressors are oriented toward increase in concentration gradients on the cell membranes (hypokalemia, hypercalcaemia, hypomagnesemia), during strong or long-term actions - toward decrease (hyperkalemia, hypocalcaemia, hypermagnesemia). Under subacute and chronic stress, before fish died, the concentrations of these ions in blood plasma (serum) were close to the norm. Thus, hyponatremia may be considered the most expressed and reliable ion indicator of malfunctioning of the organism. Many other biochemical parameters also changed noticeably following acute stress loads, while weakly reacting or not responding to subacute and chronic stress at all (for example, glucose, catecholamine s, etc.).

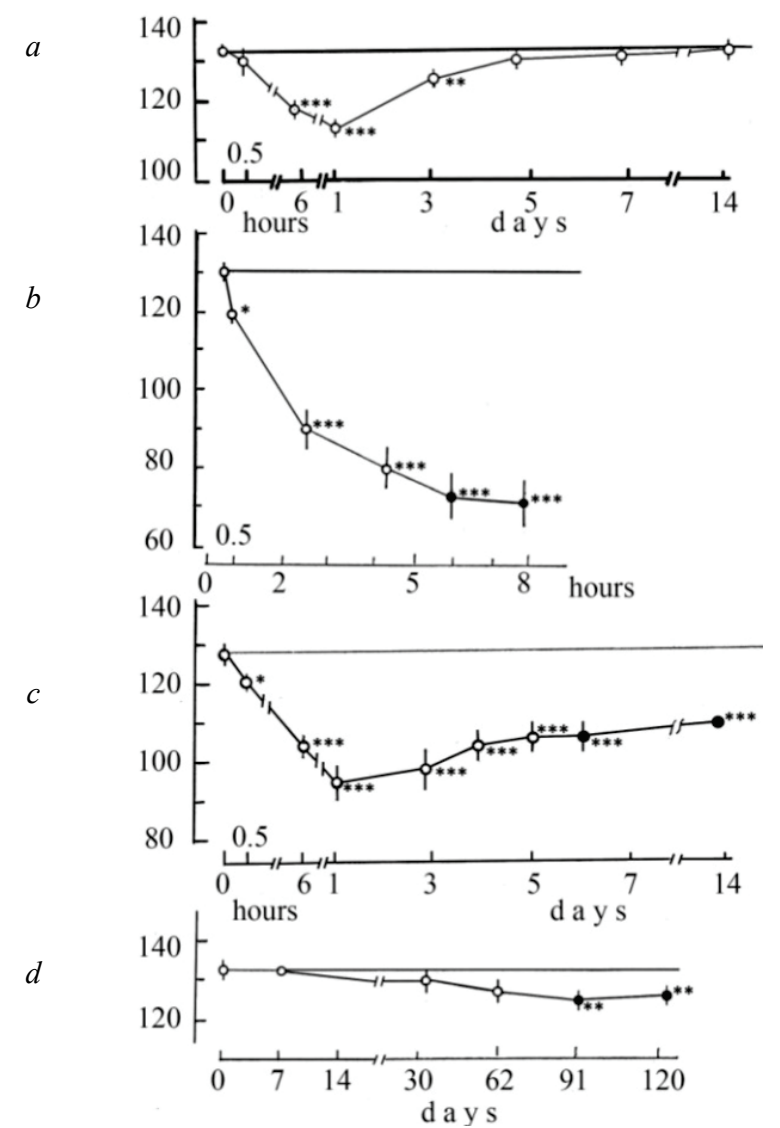

Fig. 2. Dynamics of sodium concentration in blood plasma of bream in distress (pathological stress, $\mathrm{mmol} / \mathrm{L}$ ): $a$ - acute reversible stress (duration of 1.5-2.0 h); $b, c, d,-$ respectively acute, subacute, chronic lethal stress up to the point of death of fish (dark circles indicate the condition before death); ${ }_{-}-\mathrm{P}<0.05,{ }^{* *}-\mathrm{P}<0.01,{ }^{* * *}-\mathrm{P}<0.001$ compared with the norm

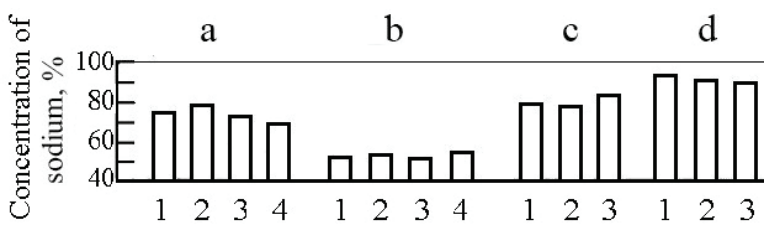

Fig. 3. Concentration of sodium in blood plasma of some fish in distress (pathological stress, $\%$ of the norm, horizontal line): $a$-acute reversible stress lasting $1.5-2.0 \mathrm{~h} ; b, c, d$-the data seen before the fish died, respectively in the conditions of acute, subacute, chronic lethal stress; 1,2,3,4-bream, roach, pike and blue bream respectively 
Changes in the concentrations of ions in blood plasma occurred under short-term weak stressors during spawning, and under long-lasting stressors after spawning (Zaprudnova \& Martemyanov, 1988).

In medicine, the important (leading) role of sodium concentration in blood serum (plasma) is first of all emphasized for the support of osmolality of the internal environment, single-cell environment, and ultimately, volume-regulation of each cell. This study has for the first time analyzed the conditions of the system of electrolyte balance of animals under stress from the perspective of the leading role of ion-concentrating gradients in the energetics of the organism. It would be more correct to talk about electrochemical gradient on the cellular membrane, but we only have concentration of sodium in the internal environment. Sodium ions take part in energization of the external membrane of animal cells: work of the sodium pump results in the functioning of most of the transport functions of cells (from epithelial to cartilage and brain cells), which are implemented not due to the consumption of energy of ATP particularly, but rather the energy of ion gradients or membrane potential (Ugolev, 1985; Natochin, 2002; Skulachev et al., 2010). Therefore, we may assume that support of constant ion composition of the internal environment of the organism (mainly sodium) is, to a larger degree, the support of the energetics of the organism, i.e. one of the most important, and perhaps priority mechanisms of survival in full-of-pressure (stressful) conditions. Thus, ion concentration gradients across the membrane of cells may be considered the reservoirs of free energy used in various physiological processes, and also as manifestation and mechanism of maintaining stable imbalance of the organism of fish as a living system.

During short weak loads and before spawning, in the organism, there forms a functioning system that is characteristic of heightened ion concentration gradients across the cell membranes and the tissues. All the remaining stress situations are characteristic of functioning systems with decreased concentration gradients. The most ineffective (due to maximum ion imbalance and minimal life expectancy) system was seen during acute stress with lethal outcome. A functioning system in the conditions of chronic stress has broad adaptive abilities: minimal ion imbalance and longer life of fish. A functioning system during subacute stress, according to value of ion imbalance and life expectancy of fish, is intermediate between the two described types. At the beginning of strong acute reversible stress, it is likely that the ion parameters may greatly deviate toward reduction of ion concentration gradients across the cell membrane and the tissues.

Based on the conducted studies, we propose the concept of two different protective reactions or two strategies of adaptations in freshwater fish in normal and extreme conditions: active and passive, which are respectively increase in the level of dysequilibrium (in energetics) and decrease in the level of imbalance (or, therefore, increase in conformity) of the organism. From the perspective of polarizing processes on the cellular membrane, the first strategy of adaptation may be defined as hyperpolarizing inhibition, and the second one as depolarizing inhibition. The first stage provides progressive development of the organism and the fullest implementation of its functions. The energy of increased ion concentration gradients across the membrane of the cells and tissues presumably determines excessive anabolic processes and increase in resistance to influence of unfavourable factors. The second strategy of adaptation provides survival in extreme conditions. During chronic stress, this is performed by minimizing the energy expenditures: due to decrease in concentration gradients and weakening of ion-transporting currents. Large losses of potassium and ammonium were seen before the death of fish. These processes ultimately determine metabolic depression. During strong acute stress, on contrary, the struggle for survival uses more energy released as a result of fast and significant decrease in ion concentration gradients for sodium (losses of sodium in the organism were much higher than losses of potassium and ammonium). During subacute stress, the struggle for survival is provided by energy of strong catabolic processes, as indicated by great losses of potassium and ammonium in the conditions of noticeably reduced concentration gradients of sodium (Zaprudnova, 2012, 2017). Thus, the evolutionary older adaptive reaction - increase in conformity of the organism - activates in extreme conditions, when the evolutionally younger adaptive mechanism that provide the disequilibrium level of a living system, necessary for normal vitality, could not be implemented.
Concentration of ions in other tissues also changes in different ways, if the stressors are of different strength and duration. For example, the concentrations of potassium and sodium in muscles - the main ion "depot" rise during influence of weak and short term actions, and decreases during strong ones (Zaprudnova, 2018). Changes of ions in erythrocytes are chiefly related to their respiratory function. At the same time, an especially important role belongs to erythrocytic manganese during influence of short-term weak stressors as one of the molecular mechanisms of reduction of oxygen uptake, and therefore, strengthening of anabolism, and thus increase in growth and development of animals (Zaprudnova, 2019). The presented provisions on the two strategies of adaptation in fish in normal and extreme conditions correlate with the provisions of Selye's theory of eustress and distress, or Arshavsky's theory of physiological and pathological stress (Dhabhar, 2008; Schreck, 2010; Schreck \& Tort, 2016).

Based on the proposed concept of two protective reactions in normal and extreme conditions or adaptation strategies - active and passive, comprising respectively increase or decrease in the level of imbalance (in energetics) of the organism, one may formulate the main principles of diagnostics of fish in natural and artificial environments according to the condition of electrolyte balance. The deviations toward decrease in ion concentration gradients across the membrane of cells and the tissues may be considered as indicators of one or the other extent of ill-being (pathology), whereas changes in opposite direction: toward increase in concentration gradients as a sign of pathology that may develop in the conditions of continuing stress. The first sign of ill-being is malfunctioning of fluctuating regime in the studied parameters (the finest level of biological organization). Transition through the phase of hypercompensation (stimulation) to the phase of reduction (depression) is a general pattern in response reaction of biological systems of different organization level to increasing stimulus or its incessant action at the same intensity. The condition of areactivity occupies an intermediate position between the phases of hypercompensation and reduction. At the same time, as mentioned above, the level of natremia is the most reliable indicator of the condition of the organism out of the 4 major cations. The most characteristic signs of active protection reaction (physiological stress, or eustress) include hypernatremia, and passive (pathological stress or distress) includes hyponatremia. Assessment of the level of natremia should take into account not only amplitude, but the time factor as well. It is important to determine the extent of stability in time of hyponatremia in the diagnostics of pathology itself (actual) in order to exclude short-term (reverse) hyponatremia during acute stress. The advantage of this parameter is low variability and some latency (retardation of changes) in the organism. For example, concentration of potassium in blood plasma changes in fish almost immediately after any action, particularly a longer period of capturing than needed (Zaprudnova, 2018).

Analysis of information in the literature about the condition of the system of electrolyte balance in mammals (chiefly humans) in stress conditions and diseases, and also the extent of the pressure an experimental object of research experiences, suggests a conclusion about the similarity of mechanisms of adaptation to stress in fish and higher vertebrates: during short-term weak loading, deviations occurring in the system of electrolyte balance are oriented toward increase in concentration gradients across the cell membrane, and toward decrease during strong or long-term loading. The most revealing work concerning this aspect was performed by Indian scientists on rats in the conditions of high hypoxia. The authors determined that raising the animals to $2-5 \mathrm{~km}$ above sea level led to hypernatriemia, then at the height of $7.5 \mathrm{~km}$, absence of reaction to the impact was observed, and further elevation to the height of $10.5 \mathrm{~km}$ led to hyponatremia and death of the animals (Purshottam \& Ghosh, 1971). As the main cause of changes in the content of ions in the tissues, the authors mention acute hypoxia. In this and other similar earlier studies, no attempts were made to determine general mechanisms of adaptation. The authors of the mentioned study (Purshottam \& Ghosh, 1971) also presented literature information about the results of studies of influence of high altitude hypoxia on content of sodium and potassium ions in the tissues of rats, dogs and human volunteers, conducted by Soviet and foreign researchers in the 1930-1960s. The analysis of these literature data allows us to conclude that they are coherent with our concept of two strategies of adaptation of animals in normal and extreme conditions: i.e. de- 
pending on strength of stressors (amount of hypoxia or height above sea level, and also time of exposure), the pattern of response reaction can take its course according to the type of hypercompensation or reduction, and also no changes may occur at all (condition of areactivity), as a result of restoration of the functions during multi-hour observations among other reasons.

The most numerous studies of ion-regulation performed on people in extreme situations were carried out by domestic and American authors on cosmonauts (and astronauts) during flights. At the same time, the researchers considered weightlessness as the main (disturbing) factor and drew no conclusions on general mechanisms of adaptation (Gazenko et al., 1980; Grigorev et al., 1996; Natochin, 2000). In short, the patterns of changes in the human system of electrolyte balance during space flights, determined by the authors, are coherent with the dependence of the pattern and extent of response reaction in fish on the amount (strength) of stressor and initial functioning condition of the organism, which we determined. Most often, after long flights, the cosmonauts were observed to have hypokalemia and hypercalciemia. In a number of cases, hypernatremia and increase in osmolarity of blood were also observed. That means, all of those are "symptoms" of physiological stress. Hypernatremia and hypercalciemia were usually observed only during the very first days after return to Earth. However, hypocalcaemia increased a week later, reaching $50 \%$. For us it is obvious that in the conditions of hyperpolarized inhibition, there occurred powerful restorative (anabolic) processes in cosmonauts who had lost weight during the flights (particularly, decrease in the volume of thighs was recorded). However, right after the take off (during transition to weightlessness), hyponatriemia was observed (i.e. shifts according to the type of pathological stress). Low hyponatremia (1.5\%) was seen after landing after short flights. We may assume that decrease in concentration of sodium in blood plasma would have been more notable if before landing the cosmonauts had not received food rich in sodium chloride. Moreover, during flights and as a result of the flights, the individual variability of the surveyed parameters increased. For example, after landing, the coefficient of sodium variability in blood plasma doubled. Individual differences in reactions to extreme conditions of flights were so high that in a number of cases, members of one crew were observed to have changes not only in the amount, but also in the orientation of response reaction.

That means that in some individuals, the shifts in the system of electrolyte regime of balance occurred as a type of physiological stress, while in others, a clear tendency was seen in the change in a number of parameters toward pathologization. Mass media reports of approximately twentyyears ago inform us that one of the cosmonauts suffered myocardial infarction during the flight. Selye classified it to idiopathic or plurocausal diseases, i.e. caused by non-specific (stress) irritators. To those categories, he also identified cancer, arthrosis, osteochondrosis, stroke and other. In other words such diseases are called adaptation diseases. Under very strong loads (space flights), it was possible to classify people based on the magnitude and orientation of ion changes according to the extent of stressresistance (health condition). During the flights and after landing, the cosmonauts were observed to have high level of aldosterone in blood and large losses of potassium in the organism, i.e. distinctive signs of stress. This shows general reaction to strong stressor related to intensive catabolism of muscle proteins. The long-duration flights led to bleaching of potassium from the bones, loss of manganese, phosphorus and number of other ions, i.e. the same negative balance of ions that takes place under strong stressors and diseases, earlier indicated by Selye.

Over the recent years, a connection has been found between hyponatremia and number of diseases: heart failure (Bettari et al.,2012; Shchekochikhin et al., 2013; Ali et al., 2016), cirrhosis (Ginés et al., 1998; Gerbes et al., 2003; Ginès \& Guevara, 2008), kidney failure (Pérez-García et al., 2016; Zhang et al., 2017), cancer (Berghmans et al., 2000; Castillo et al., 2016; Workeneh et al., 2020), alcoholism (Limias et al., 2000; Stasiukynienè, 2002), and also age (Wannamethee et al., 2016). Hyponatremia was observed in patients during the post-surgery period (Leung, 2012; Leise \& Findlay, 2017). Thus, in general, hyponatremia was observed to accompany adaptation diseases. Connection of hyponatremia with adaptation diseases, especially heart failure, cirrhosis and oncogenesis, was a subject of many studies (several times more than presented here), but the present article, due to its limited volume, cannot provide that many references. Higher mortality and longer duration of hospital treatment was determined with patients with hyponatremia than with normonatriemia. Kutina and the co-authors (Kutina et al., 2005), in their study, which contains references to over 450 literature sources, based on their own and literature data, suggest that the normal levels of natremia in healthy person equal $141.0 \pm 2.3 \mathrm{mmol} / \mathrm{L}$. Despite the fact that the authors had not concluded that there is a connection between the levels of ions in the internal environment and stress, the study nonetheless suggests that frequently occurring hyponatremia in humans is evoked by one or the other stressor or disease. For example, the authors mention that hyponatremia develops more often in children receiving long term hospital treatment, regardless of pathology or age, and it may be an indicator of development of sepsis, and also was observed in patients suffering severe forms of malaria. Hypernatremia, rarely recorded by the authors, was caused by the action of a short term stressor on healthy trained people.

Nevertheless, the literature contains suggestions for treating hyponatremia during various diseases, mainly heart failure, cardiovascular failure using receptor blockers in the kidneys of vasopressin hormone (antidiuretic hormone) (Greenberg, 2010; Sahay \& Sahay, 2014; De Vecchis et al., 2017). However, as our work suggests, the treatment and especially liquidation of the causes (if possible) may be the most effective means of treating hyponatremia. Likewise, the disease itself may be an endogenous stressor. On fish, it was shown that in the initial period of the disease, the changes in concentration of ions in the tissues of fish were aimed at elevation in concentration gradients across the membrane of cells (hypercompensation), and during the late stages of the disease - decrease (reduction). This is relevant for both contagious (Limanskii, 1984; Zaprudnova, 2018) and non-contagious diseases (Natochin et al., 1995).

Changes in the concentration of ions in patients (the organs) suffering adaptation diseases also occur according to the type of reduction, i.e. toward decrease in concentration gradients across the membrane of cells and tissues. Selye observed decrease in concentrations of potassium and increase in sodium in the cardiac muscle in patients suffering myocardial infarction. Further, such a dynamic in ion content of the heart muscle, as well as changes according to the type of reduction in the internal environment, were seen by many researchers. The authors determined direct dependence of the degree of damage to the heart muscle on the decrease in the concentration gradients of sodium and potassium across the membranes of cells. With improvement of the clinical condition of patients, ion composition in the tissues normalized. As known, during oncogenesis, ion composition of diseased cells changes according to the reduction type (Malenkov, 1976).

However, during strokes (brain ischemia or brain hemorrhage), also related to adaptation diseases, both hyponatremia and hypernatremia were recorded in earlier studies (Vilenskii et al., 1998; Carcel et al., 2016; Murphy, 2016). Perhaps, in this case, we need to consider specific changes in the system of electrolyte exchange. We may assume that during ischemia or brain bleed, the nervous structures related with hormone regulation of electrolyte exchange (hypothalamus, pituitary gland) become damaged, for example, vasopressin is being generated insufficiently (antidiuretic hormone) thus weakening the action of the hormone toward the corresponding cell receptors. Hypernatremia may also occur during depression (Ozdemir, 2013). During this disease, the deficit of the influence of antidiuretic hormone on renal structures is likely related to excessive influence of it on the corresponding brain structures.

Therefore, a question arises of why dependence of the pattern of response reaction of the electrolyte balance system on the amount (strength and duration) of stressor has not been seen in higher vertebrates? There may be two main reasons for this. First of all, in medicine and other spheres of biology, on higher vertebrates, i.e. directly or indirectly related to medicine, the priority is still the study of specific component of response reaction (i.e. quality to the disadvantage of quantity) and significantly less attention is paid to the study of general mechanisms of adaptation. First of all, there are specific reasons of the disease, associated for example with excess or deficiency of the action of hormones that regulate electrolyte balance of the organism, and also with disorders in consumption of water and salt, both arbitrary and not. The second reason is the high level of homeostasis in mammals, which manifests both in narrower range of 
deviations of ion content from the normal values and in the rarely applied strategy according to the reduction type. Increase in homeostasis should be considered as one of most the important signs of progressing evolution of the system of electrolyte balance. In other words, in lower aquatic vertebrates, dependence of the changes in the system of electrolyte balance on the amount of stressor is easier to detect. Deviations according to the reduction type in fish are more common and occur more often than in higher vertebrates. Reversible hyponatremia during action of strong stressors, as demonstrated in the study, may reach $30 \%$. The same amount and longer duration is possible for reversible hyponatremia in dormant fish in low water temperatures (Zaprudnova, 2005). In mammals, even during quite prolonged action of a strong stressor leading to the development of a triad of pathologies (increase in the cortex of the adrenal glands, involution of status thymicolymphaticus, ulcer of stomach and intestine), the organism prefers to maintain sodium homeostasis (absorbing or containing high amounts of sodium) while experiencing high losses of potassium. The situations analyzed above, which occurred during excessive loads in the conditions of space flights, are examples of slight deviation of sodium in the internal environment from the norm according to the reduction type. Only specific changes in the system of electrolyte balance during various diseases (for example, syndrome of inadequate secretion of antidiuretic hormone, deficiency of adrenocorticotropic hormone and others) represent greater deviations of sodium concentration in the internal environment (usually up to 15-16\%) (Kutina et al., 2005). Hyponatremia in higher vertebrates in acute lethal cases is lower than in fish (Purshottam \& Ghosh, 1971).

That being said, the broad range of fluctuations of normal values of sodium concentrations in blood plasma in humans $(130-150 \mathrm{mmol} / \mathrm{L})$, reported in many books over several decades, is surprising. Possibly, the currently proposed normal range of natremia in humans is also quite wide: $135-145 \mathrm{mmol} / \mathrm{L}$. This is even stranger because we observed fish that belong to lower vertebrates to have a narrow range of the normal values of natremia: in bream, for example, it equaled $130-133 \mathrm{mmol} / \mathrm{L}$ in the normal laboratory conditions and ecologically clean districts of the Rybinsk Reservoir (Zaprudnova, 2018). Even slight deterioration in the maintenance conditions of fish in the laboratory caused low (2-4\%) hyponatremia (Zaprudnova, 1999), and bream in ecologically unfavourable districts could be observed to have low hypo- and hypernatremia, and normonatremia (condition of areactivity) depending on time and intensity of the action of the stressor (Zaprudnova, 2018). After significant exacerbation of ecological circumstances as a result of large industrial accidents, sodium concentration in the blood plasma of bream could drop down to $80 \mathrm{mmol} / \mathrm{L}$ (Martemyanov, 2014). However, we should recognize that in the studies on humans, there already are emerging researches reporting a narrower range of normal values of natremia. Therefore, sodium concentration in blood plasma equaling 136 and $138 \mathrm{mmol} / \mathrm{L}$ was considered a marker of mortality and risk of cardio-vascular diseases in elderly men (Wannamethee et al., 2016).

In the times of Selye, the role of retention of sodium and water in the organism during stress, evoked by elevation of aldosterone in blood and accompanied by strengthening of inflammatory processes in the tissues and rise in blood pressure, has been unclear. Later, aldosterone was found to be associated with an increased risk of death from cardio-vascular diseases (Tomaschitz et al., 2010). The adaptive significance of this hormone may be explained from the perspective of energetic role of sodium potential. Among hormones in fish, a function similar to aldosterone, aimed at preservation of sodium in the organism under stress, was performed by prolactin and cortisol influencing the gill epithelium.

The results of our own researches on fish and analysis of the literature material on the condition of the system of electrolyte balance in mammals during stress and diseases allows us to conclude that maintenance of constancy of ion content in the internal environment (mainly sodium), is, to a significant degree, the support of energetics of the organism, i.e. one of the most important and maybe prior mechanisms of survival under pressure (stress). While not denying the existence of specific reasons for hyponatremia, we consider it in most cases as a system reaction, or it indicates decrease in the energetics of the organism. This is especially evident during adaptation diseases. The level of sodium in plasma (serum) of blood may be a reliable indicator of the organism's condition.

\section{Conclusions}

During the influence of strong or long-term stressors of various quality, sodium concentration in the internal environment of fish changed toward decrease in concentration gradients across the cellular membrane (hyponatremia, distress or pathological stress), during the influence of weak and short-term - toward increase in ion concentration gradients (hypernatremia, eustress or physiological stress). Judging from the literature data, changes in ion composition of the internal environment of higher vertebrates during stress are similar to those of fish. In the present research, for the first time the analysis of the condition of the system of electrolyte balance of animals during stress was made from the perspective of the leading role in the organism's energetics of ion concentration gradient across the membrane of cells. The study suggests that there are two different strategies of adaptation depending on intensity of the action of stressor: active and passive. Hyponatremia that accompanies many diseases in people (mainly, diseases of adaptation) is supposedly a non-specific reaction of the organism and an indicator of decreased energetics of the organism. Sodium level in the internal environment of the organism is proposed for diagnostics of stress condition of animals.

\section{References}

Akbary, P. (2014). Consideration of blood serum biochemical parameters of yellow fin sea bream (Acantopagrus latus Houttuyn, 1782) and orange-spotted grouper (Epinephelus coioides Hamilton, 1822). Advances in Biological Chemistry, 4, 407-413.

Ali, K., Workicho, A., \& Gudina, E. K. (2016). Hyponatremia in patients hospitalized with heart failure: A condition often overlooked in low-income settings. International Journal of General Medicine, 9, 267-273.

Ball, S. G., \& Iqbal, Z. (2016). Diagnosis and treatment of hyponatraemia. Best Practice and Research. Clinical Endocrinology and Metabolism, 30(2), 161-173.

Berghmans, T., Paesmans, M., \& Body, J. J. (2000). A prospective study on hyponatraemia in medical cancer patients: Epidemiology, aetiology and differential diagnosis. Supportive Care in Cancer, 8(3), 192-197.

Bettari, L., Fiuzat, M., Felker, G. M., \& O'Connor, C. M. (2012). Significance of hyponatremia in heart failure. Heart Failure Reviews, 17(1), 17-26.

Carcel, C., Sato, S, Zheng, D., Heeley, E., Arima, H., Yang, J., Wu, G., Chen, G., Zhang, S., Delcourt, C., Lavados, P., Robinson, T., Lindley, R. I., Wang, X., Chalmers, J., \& Anderson, C. S. (2016). Prognostic significance of hyponatremia in acute intracerebral hemorrhage: Pooled analysis of theintensive blood pressure reduction in acute cerebral hemorrhage trial studies. Critical Care Medicine, 44(7), 1388-1394.

Castillo, J. J., Glezerman, I. G., Boklage, S. H., Chiodo III, J., Tidwell, B. A., Lamerato, L. E., \& Schulman, K. L. (2016). The occurrence of hyponatremia and its importance as a prognostic factor in a cross-section of cancer patients. BMC Cancer, 16, 564.

De Vecchis, R., Cantatrione, C., \& Mazzei, D. (2017). Vasopressin receptor antagonist in patients with chronic heart failure. Herz, 42(5), 492-497.

Dhabhar, F. S. (2008). Enhancing versus suppressive effects of stress on immune function: Implications for immunoprotection versus immunopathology. Allergy, Asthma and Clinical Immunology, 4, 2-11.

Gazenko, O. G., Grigorev, A. I., \& Natochin, Y. V. (1980). Vodno-solevoj gomeostaz i nevesomost' [Water-salt homeostasis and weightlessness]. Kosmicheskaja Biologija i Aviokosmicheskaja Meditsina, 5, 3-10 (in Russian).

Gerbes, A. L., Gülberg, V., Ginès, P., Decaux, G., Gross, P., Gandjini, H., Djian, J., \& VPA Study Group (2003). Therapy of hypona-tremia in cirrhosis with a vasopressin receptor antagonist: A randomized double-blind multicenter trial. Gastroenterology, 124(4), 933-939.

Ginès, P., \& Guevara, M. (2008). Hyponatremia in cirrhosis: Pathogenesis, clinical significance, and management. Hepatology, 48(3), 1002-1010.

Ginés, P., Berl, T., Bernardi, M., Bichet, D. G., Hamon, G., Jiménez, W., Liard, J.-F., Pierre-Yves Martin, P.-J., \& Schrier, R. W. (1998). Hyponatremia in cirrhosis: From pathogenesis to treatment. Hepatology, 28(3), 851-864.

Greenberg, B. (2010). Managing hyponatremia in patients with heart failure. Journal Hospital Medicine, 5(3), S33-S39.

Grigorev, A. I., Larina, I. M., Noskov, V. B., Menshutkin, V. V., \& Natochin, Y. V. (1996). Vlijanie neprodolzhitelnykh i dlitelnykh kosmicheskikh poletov na nekotorye biokhimicheskie i fiziko-khimicheskie parametry krovi kosmonavtov [Influence of short and long space flights on some biochemical and physicochemical parameters of cosmonauts' blood]. Aviakosmicheskaja i Ekologicheskaja Meditsina, 1, 4-10 (in Russian).

Henry, D. A. (2015). In the clinic: Hyponatremia. Annals of Internal Medicine, 163(3), ITC1-ITC19. 
Kutina, A. V., Kuznetsova, A. A., \& Natochin, Y. V. (2005). Kationy v syvorotke krovi cheloveka [Cations in human serum]. Uspekhi Fiziologicheskih Nauk, 36(3), 3-32 (in Russian).

Lee, J. J., Kilonzo, K., Nistico, A., \& Yeates, K. (2014). Management of hyponatremia. Canadian Medical Association Journal, 186(8), E281-E286.

Leise, M. D., \& Findlay, J. Y. (2017). Hyponatremia in the perioperative period: When and how to correct. Clinical Levers Desease. A Multimedia Review Journal, 9(5), 111-114.

Leung, A. A., McAlister, F. A., Rogers Jr., S. O., Leung, A., McAlister, F. A., Rogers Jr., S., Pazo, V., Wright, A., \& Bates, D. W. (2012). Preoperative hyponatremia and perioperative complications. Archives of Internal Medicine, 172(19), 1474-1481

Liamis, G. L., Milionis, H. J., Rizos, E. C., Siamopoulos, K. C., \& Elisaf, M. S. (2000). Mechanisms of hyponatraemia in alcohol patients. Alcohol and Alcoholism, 35(6), 612-616.

Limanskii, V. V., Martem'yanov, V. I., Bekina, E. N., \& Golovina, N. A. (1984). Izmenenie elektrolitnogo sostava krovi i myshts pri zarazhenii karpa Ichthyophtirius multifilus (Ciliata, Ophryogenidae) [Changes in the electrolyte composition of blood and muscle during the infection of carp Ichthyophtirius multifilus $(\mathrm{Ci}$ liata, Ophryogenidae)]. Parazitologiya, 18(6), 478481 (in Russian).

Malenkov, A. G. (1976). Ionnyj gomeostaz i avtonomnoe povedenie opukholi. [Ionic homeostasis and tumor autonomic behavior]. Nauka, Moscow (in Russian).

Martemyanov, V. I. (2014). Otsenka ostrogo i khronicheskogo stressa u presnovodnykh ryb po pokazatelyam vodno-solevogo obmena [Assessment of acute and chronic stress in freshwater fish by indicators of water-salt metabolism]. Uspekhi Sovremennoy Biologii, 134(6), 573-581 (in Russian).

Muhsin, S. A., \& Mount, D. B. (2016). Diagnosis and treatment of hypernatremia. Best Practice and Research. Clinical Endocrinology and Metabolism, 30(2), 189-203.

Murphy, C. V. (2016). Intracerebral hemorrhage: Please pass the salt. Critical Care Medicine, 44(7), 1443-1444.

Natochin, Y. V. (2000). Novoe o prirode regulyacii v organizme cheloveka [New about the nature of regulation in the human body]. Vestnik RAN, 70(1), 21-35 (in Russian).

Natochin, Y. V. (2002). Evolution of the water-salt balance: From phenomenology to mechanisms of physiological function. Jornal of Evolutionary Biochemistry and Physiology, 38(5), 586-597.

Natochin, Y. V., Luk'yanenko, V. I., Shakhmatova, E. I., Lavrova, E. A., \& Metallov, G. F. (1995). Dvadtsatiletniy monitoring (70-90-e gody) fiziko-khimicheskikh parametrov syvorotki krovi u russkogo osetra Acipenser gueldenstaedti [Twenty years of monitoring (1970-1990-th years) physico-chemical parameters of blood serum in the Russian sturgeon Acipenser gueldenstaedti]. Voprosy Ikhtiologii, 35(2), 253-257 (in Russian).

Ozdemir, O. (2013). Sodium and depression: Hypothetical associations, klinik psikofarmakoloji bülteni. Bulletin of Clinical Psychopharmacology, 23(1), 107-112.

Pérez-García, R., Palomares, I., Merello, J. I., Ramos, R., Maduell, F., Molina, M., Aljama, P., Marcelli, D., \& en representación del grupo ORD (2016). Hyponatraemia, mortality and haemodialysis: An unexplained association. Nefrología, 36(1), 42-50.

Reynolds, R. M., Padfield, P. L., \& Seckl, J. R. (2006). Disorders of sodium balance. British Medical Journal, 332(7543), 702-705.

Sahay, M., \& Sahay, R. (2014). Hyponatremia: A practical approach. Indianan Journal Endocrinology Metabolism, 18(6), 760-771.

Schreck, C. B. (2010). Stress and fish reproduction: The roles of allostasis and hormesis. General and Comparative Endocrinology, 165(3), 549-556.

Schreck, C. B., \& Tort, L. (2016). The concept of stress in fish. Biology of stress in fish. Fish Physiology, 35(1), 1-34.

Selik, E. S. (2004). Blood chemistry (electrolytes, lipoproteins and enzymes) values of black scorpion fish (Scorpena porcus Linneaus, 1758) in the Dardanelles, Turcey. Journal of Biologicai Sciences, 4(6), 716-719.
Skulachev, V. P., Bogachev, A. V., \& Kasparinskiy, F. O. (2010). Membrannaya bioenergetika [Membrane bioenergetics]. Moscow State University, Moscow (in Russian).

Stasiukynienè, V. (2002). Blood plasma potassium, sodium and magnesium levels in chronic alcoholic patients during alcohol with-drawal. Medicine (Kaunas), 3(9), 892-895.

Tomaschitz, A., Pilz, S., Ritz, E. A., Meinitzer, A., Boehm, B. O., \& März, W. (2010). Plasma aldosterone levels are associated with increased cardiovascular mortality: The Ludwigshafen Risk and Cardiovascular Health (LURIC) study. European Heart Journal, 31(10), 1237-1247.

Ugolev, A. M. (1985). Evolyutsiya pishchevareniya i printsipy evolyutsii funktsiy: Elementy sovremennogo funktsionalizma [Evolution of digestion and the principles of the evolution of functions: Elements of modern functionalism.]. Nauka, Leningrad (in Russian).

Vilenskii, B. S., Natochin, Y. V., Semenova, G. V., \& Sulima, V. V. (1998). Snizhenie letal'nosti pri korrektsii vodno-solevogo obmena v sisteme bazisnoi terapii ishemicheskogo insul'ta [Lowering of mortality in water-salt metabolism correction in basic therapy of ischemic stroke]. Zhurnal Nevrologii i Psikhiatrii imeni C. C. Korsakova, 10, 38-40 (in Russian).

Wannamethee, S. G., Shaper, A. G., Lennon, L., Papacosta, O., \& Whincup, P. (2016). Mild hyponatremia, hypernatremia and incident cardiovascular disease and mortality in older men: A population-based cohort study. Nutrtion, Metabolism and Cardiovascular Disease, 26(1), 12-19.

Workeneh, B. T., Jhaveri, K. D., \& Rondon-Berrios, H. (2020). Hyponatremia in the cancer patient. Kidney International, 98(4), 870-882.

Zaprudnova, R. A. (1999).Vliyanie temperatury akklimatsii na soderzhanie ionov v plazme krovi, eritrotsitah i myshtsah u lescha Abramis brama [Influence of acclimation temperature on the content of ions in blood plasma, erythrocytes and muscles in bream Abramis brama]. Voposy Ichthyologii, 39(3), 410-415 (in Russian).

Zaprudnova, R. A. (2005). Povedenie i ionnaya regulyatsiya u presnovodnyh ryb v nizkih subletal'nyh temperaturah [Behavior and ionic regulation in freshwater fish at low sublethal temperatures]. In: Povedenie Ryb. Materialy Mezhdununarodnoj Konferencii. Akvaros, Moskow. Pp. 158-162 (in Russian).

Zaprudnova, R. A. (2012). Obmen i regulyatsiya kationov u presnovodnykh ryb v normal'nykh i ekstremal'nykh usloviyakh [The exchange and regulation of cations of freshwater fish in normal and extreme conditions]. In: Fiziologicheskie, biokhimicheskie i molekulyarno-geneticheskie mekhanizmy adaptatsiy gidrobiontov. Acvaros, Moscow. Pp. 147-150 (in Russian).

Zaprudnova, R. A. (2017). Neprodolzhitel'noe deystvie nesil'nykh stressorov na kontsentratsiyu kationov v plazme krovi leshcha [Short-term effect of weak stressors on the concentration of cations in plasma of blood of the bream]. Trudy IBVV RAN, 78, 77-89 (in Russian).

Zaprudnova, R. A. (2018). Otsenka sostoyaniya volzhskikh populyatsii leshha $A b$ ramis brama po ionnym pokazatelyam [Assessment of the state of the Volga populations of the bream Abramis brama by ionic indicators]. Trudy IBVV RAN, 82, 96-116 (in Russian).

Zaprudnova, R. A. (2019). Uchastie eritrocitarnogo magniya v stressornyh reakciyah ryb [Participation of erythrocyte magnesium in stress reactions of fish]. Trudy IBVV RAN, 88, 29-40 (in Russian).

Zaprudnova, R. A., \& Martem'yanov, V. I. (1988). Sezonnye izmeneniya kontsentratsii kationov v plazme krovi presnovodnykh ryb [Seasonal changes in cation concentration in blood plasma of freshwater fish]. Voprosy Ikhtiologii, 28(4), 671-676 (in Russian).

Zhang, R. S., Wang, S., Zhang, M., \& Cui, L. (2017). Hyponatremia in patients with chronic kidney disease. Hemodialysis International, 21(1), 3-10. 